\title{
The Interaction between Ownership Concentration and Market Risk in European, American and Chinese Markets: the Effects of BREXIT
}

\author{
${ }^{1}$ Kaunas University of Technology \\ K. Donelaicio st. 73, LT-44029, Kaunas, Lithuania \\ E-mail.jurgita.bruneckiene@ktu.lt; jonas.rapsikevicius@ktu.lt \\ ${ }^{2}$ Vytautas Magnus University \\ K. Donelaicio str. 58, LT-44248, Kaunas, Lithuania \\ E-mail.sarunasmikalonis@gmail.com
}

Jurgita Bruneckiene $^{1}$, Sarunas Mikalonis ${ }^{2}$, Jonas Rapsikevicius ${ }^{1}$

cross $^{\text {ref }}$ http://dx.doi.org/10.5755/j01.ee.31.5.25997

\begin{abstract}
Today's economy is facing various economic shocks, for instance BREXIT, that do not have any evidence from the past. Economic shocks directly affect market risks, the characteristics of which are observed by business company managers before making investment and operational decisions. Such decisions are directly affected by corporate ownership concentration and structure. The issue of ownership concentration in literature lacks approach when it is analysed in the interaction with market risk, caused by an economic shock. The contribution of this research to the discipline is the interaction between the indicators that reflect the impact of ownership concentration on corporate market risk by an economic shock (regression model was created). This model is proposed as a methodological tool to assess and analyse the scientific problem in question; it can also serve as a new and reliable instrument for business decision-makers and managers. An example of the data analysis representing European, American and Chinese markets as well as the United Kingdom as a country of origin of the economic shock under consideration is provided. The research proves that there exist statistically significant differences in the interaction between ownership concentration and corporate market risk in different markets. Also, it was found that BREXIT most significantly raised the risk in the UK market, as in the country of origin, in comparison to the risk observed in other markets. This paper contributes to the literature in corporate management decisions and systemic risk management; it also sheds light upon the economic-financial effects of the BREXIT process. Practical implication of this research is related to a focus on a detailed measurement instrument which allows to assess the systemic risk from a corporate management perspective.
\end{abstract}

Keywords: Ownership Concentration; Corporate; Market Risk; Brexit; European, American and Chinese Markets.

\section{Introduction}

Each agent that invests in a business company with a view of finding the best profit-risk ratio in the market considers not only economic-financial business results, but also the ownership structure. Shareholder equity concentration, which represents the decision-making freedom provided to business managers, directly affects business results and share price fluctuations through investment, funding and borrowing decisions. Higher ownership concentration can have a greater impact on the decisions made. Shareholder ownership structure determines the level of business monitoring and investor risk assessment.

The multiple effects of shareholder ownership concentration lead to popularity of this topic among scholars and practitioners. Researchers typically analyse the relationship between shareholder equity concentration and corporate financial performance, borrowing rates and profitability (Barinov, 2017; Feng et al., 2016; Leung et al., 2014; Cabrera-Suarez \& Martin-Santana, 2014; Manzaneque et al., 2016). Nevertheless, a lack of the research into the interaction between ownership concentration and corporate market risks is still observed. The studies that assess the interaction between shareholder ownership structure and market risks commonly cover the banking sector and focus on credit and bankruptcy risks (Battaglia \& Gallo, 2017; Dong et al., 2014).

The relevance of the research into the interaction between ownership concentration and corporate market risks is determined by constant recurring of economic shocks that affect the level of risks in the market. Destructive economic shocks, in turn, reduce the amount of the investment attracted, diminish funding availability and raise market risks (Grossule, 2019; Welfens, 2019). Moreover, economic shocks reduce the demand for a significant part of a company's goods and services which means that business survivability is decreasing (Grossule, 2019). Coronavirus and BREXIT caused economic shocks that have a significant impact on today's economy, have no evidence from the past and, therefore, call for comprehensive research.

The impact of ownership concentration on an entity's market risk may vary from region to region. Companies located in different regions operate under a more or less developed legal framework which forms investors' sense of safety (Chen et al., 2017). The amount, availability and reliability of the information disclosed to investors may also vary. The different levels of national economic development form investors' attitudes towards an enterprise and may 
affect investors' expectations concerning business future (Chen et al., 2017).

The purpose of this article is to investigate the interaction between a company's ownership concentration and market risks caused by the BREXIT process in the European, American and Chinese markets as well as in the United Kingdom as a country of origin of the economic shock under consideration.

The contribution of this paper is threefold. First, it contributes to the gap in the literature with a new approach since previously ownership concentration was commonly linked to economic-financial results of business enterprises. Second, it reveals the impact of the BREXIT process on corporate market risks. For instance, it disclosed that the UK is more exposed to the systemic risk than the rest of the EU due to the fact that it is going to leave a joint risk management system (Grossule, 2019; Welfens, 2019). Hence, our research results contribute to the empirical assessment of the effects caused by the BREXIT process. Third, this paper supplements corporate risk management literature with an ordinary least squares regression model which combines Beta risk as a dependent variable and CEO duality, venture capital owned stocks and private equity fund owned stocks as main independent variables. Furthermore, by considering return on equity, corporate debt ratio, current liquidity ratio and revenue growth rate as main control variables, this paper provides original empirical evidence on the interaction between ownership concentration and corporate market risk in the European, American and Chinese markets caused by the BREXIT process.

This paper proceeds in the following manner. At first, it presents the manifold impact of ownership concentration on corporate performance and analyses its interaction with market risk. Based on the theoretical analysis, the conceptual framework for assessing the interaction between ownership concentration and corporate market risk caused by an economic shock is developed. Thereafter, the paper introduces the research methodology and the hypotheses raised. The empirical findings and the discussion are presented in the next section. The paper concludes with the synthesis of the most important insights and the comments on the research limitations and possibilities for further research.

The research methods include meta-analysis of scientific literature, regression models and analysis. The data was collected by using Bloomberg and OECD databases. Time frame of the research holds regions macroeconomic and companies' financial and corporate governance data for 2016 and 2018 years.

\section{Literature Review}

Ownership structure and concentration have a multifaceted impact on corporate decisions and performance. Most researchers (Drobetz et al., 2019, Barinov, 2017, Stepanov \& Suvorov 2017, Manzaneque, et al., 2016, Feng et al., 2016, Leung et al., 2014; Cabrera- et al., 2014) analyse the links between ownership concentration and borrowing, investment, funding or stock value. Companies with different levels of ownership concentration are characterised by different borrowing cultures (Sun et al., 2016): the ones with a high level of ownership concentration are typically associated with lower indebtedness to banks and a greater willingness to fund their operations from internal sources and share issues, while the ones with a low level of ownership concentration are more likely to opt borrowing from banks which is often cheaper. More active discussions take place when analysing the relationship between ownership concentration and efficiency of investment decisions. Due to the impact of shareholders, the companies with a high level of ownership concentration are more likely to make less efficient investment decisions (Gonzalez et al., 2016), whereas the companies with a low level of ownership concentration tend to make more efficient investment because the latter ones are more insightful about their market potential and are subject to less shareholder pressure. The impact ownership concentration has on corporate investment decisions depends on the composition of ownership concentration in particular companies, except the cases when the largest part of ownership is held by business angels (Wen \& Xia, 2016). Differences in the return on the shares in family-owned companies compared to the return on the shares in the companies with a different capital structure listed on the Swiss Stock Exchange indicate (Eugster \& Isakov, 2019) that the companies with a family-owned shareholding structure generate statistically significantly higher stock returns. In addition, market risk faced by family-owned companies is much lower than that faced by the companies which do not possess this type of shares in their ownership structure.

Scientific literature is dominated by the studies addressing the relationship between ownership concentration and corporate performance (Drobetz et al., 2019, Barinov, 2017), capability of borrowing (Barinov, 2017, Manzaneque et al., 2016, Feng et al., 2016) and making efficient investment (Leung et al., 2014; Cabrera-Suarez \& MartinSantana, 2014). Nevertheless, there still is a visible lack of research into the impact of ownership concentration and structure on corporate market risks rather than on corporate financial performance.

Some studies (Zhai \& Ma, 2017, Feng, Hu, Johansson, 2016; Gonzalez et al., 2016; Arosa, 2010; Cabrera-Suarez, Martin-Santana, 2014; Ding et al., 2013; Hou et al., 2012; Leung et al., 2014; Prommin et al., 2016; Sun et al., 2016; Vintila \& Gherghina, 2014; Farrer \& Ramsay, 1998) confirm that there exists a strong relationship between ownership concentration and market risk which, in its turn, forms management behaviour, investment and business funding decisions. A potential investor, however, also analyses a company's ownership structure and assesses what risks this company faces and what decisions can therefore be expected. Companies located in different regions operate under a more or less developed legal framework which forms investors' sense of safety, thus investor, working in a different market might take different actions based on the market signals (Chen et al., 2017). The amount, availability and reliability of the information disclosed to investors may also vary in the different markets. The different level of national economic development form investors' attitudes towards an enterprise and may affect investors' expectations concerning business future (Chen et al., 2017). 
Market risk is affected by a number of factors (Silva $e t$ al., 2016; Barunik \& Krrehlik, 2018; Neveu, 2018) that differently affect both the risk itself and corporate investment and operational decisions. Economic shocks directly affect market risks. BREXIT is one of the current economic shocks. Although it is a geopolitical process, it can also be considered as an economic shock in terms of systemic risk. Firstly, this consideration can be justified through the prism of a shortterm change which affects the economy and stability of the financial system, and which, in fact, is basically referred to as an economic shock (Barunik \& Krrehlik, 2018). Secondly, in contrast to the prism of systemic risk used for assessment of economic shocks, i.e. the situation when shocks rise externally and thus affect the interconnectedness of the financial systems (Neveu, 2018) within the EU and the UK, BREXIT-caused economic changes can be considered as an internal factor because they occurred in the local market.

The experience of the recession of 2008 demonstrated how important it is to assess shock-affected macroeconomic environment, market risks and to improve the traditional models developed for the analysis of systemic risk and potential spread of shocks in financial systems (Silva et al., 2016). Recent economic shocks (namely BREXIT and the COVID-19 pandemic) do not possess any evidence from the past, and corporate reactions to these shocks are different from those observed during common financial or banking crises. For the reasons explicated above, the assessment of market risks under the conditions of the economic shock caused by the BREXIT geopolitical process is extremely relevant. Recent media reports along with Bloomberg's data indicate that the COVID-19 pandemic has a significant impact on financial and market indicators: they substantiate that the pandemic has caused health, demand, supply, finance and labour market crisis leading to the difficulties and new challenges for businesses. A deeper insight in this issue will, however, require additional time and is going to be an area for future studies.

The impact of the BREXIT process on market risks was wider analysed by Batsaikhan et al. (2017), Danielsson et al (2017) and Bailey et al. (2018). Upon its decision to leave the EU single market, the United Kingdom is adversely affected by the dismissal of the common regulatory and financial system, which will eventually increase the systemic risk (Grossule, 2019; Welfens, 2019). The United Kingdom market will also suffer the negative effects of BREXIT in terms of a decrease in its FDI and employment rates directly linked to the stability of the financial system (Batsaikhan et al., 2017, Bailey et al., 2018). The studies of the abovementioned scientists prove that the ongoing BREXIT process has already led to a reduction in FDI in the United Kingdom, and the uncertainty about the conditions under which the UK businesses will have to trade with the rest of the world after the moment of the final exit from the EU led to a visible increase in the market risk faced by the UK business companies in 2018. Market uncertainty of the Brexit also cost lower consumption of the UK`s households (Steinberg, 2019) which means that the demand in the market lowers for the services and goods, increasing the difficulties and market risk created by the Brexit for the local companies (Steinberg, 2019). Moreover, the Brexit increased market trade volatility for UK`s companies ( $\mathrm{Li}, 2020)$ at the same time meaning the increasement of the companies markets risk due to the market uncertainty.

Some other studies (Arosa, 2010; Cabrera-Suarez, Martin-Santana, 2014; Ding et al., 2013; Farrer \& Ramsay, 1998; Feng et al., 2016; Gonzalez et al., 2016; Hou et al., 2012; Leung et al., 2014; Prommin et al., 2016; Sun et al., 2016; Vintila \& Gherghina, 2014; Zhai \& Ma, 2017) focused on the relationship between market risk and ownership concentration cover a single country or a single region, but the results recorded in different regions or sectors are rarely compared. Minding the fact that economic shocks more or less affect all markets simultaneously (Batsaikhan et al., 2017, Bailey et al., 2018), the necessity of a cross-market comparison arises.

The effects of corporate ownership concentration are usually assessed by employing various econometric models: hierarchical linear model (Bao \& Lewellyn, 2017); ordinary least squares model (Ben-Nasi \& Cosset, 2014); ordered logistic regression model (Gonzalez et al., 2016, Haw et al., 2013). A statistical analysis without any econometrical modelling is employed very occasionally (Campbell, 2015).

The analysis of previous scientific studies (Barinov, 2017; Feng et al., 2016; Leung et al., 2014; Cabrera-Suarez \& Martin-Santana, 2014; Manzaneque et al., 2016; Drobetz et al., 2019; Arosa, 2010; Ding et al., 2013; Farrer \& Ramsay, 1998; Gonzalez et al., 2016; Hou et al., 2012; Prommin et al., 2016; Sun et al., 2016; Vintila \& Gherghina, 2014; Zhai \& $\mathrm{Ma}, 2017)$ allowed to develop the conceptual framework for the analysis of the interaction between ownership concentration and market risk under the conditions of an economic shock (see Figure 1).

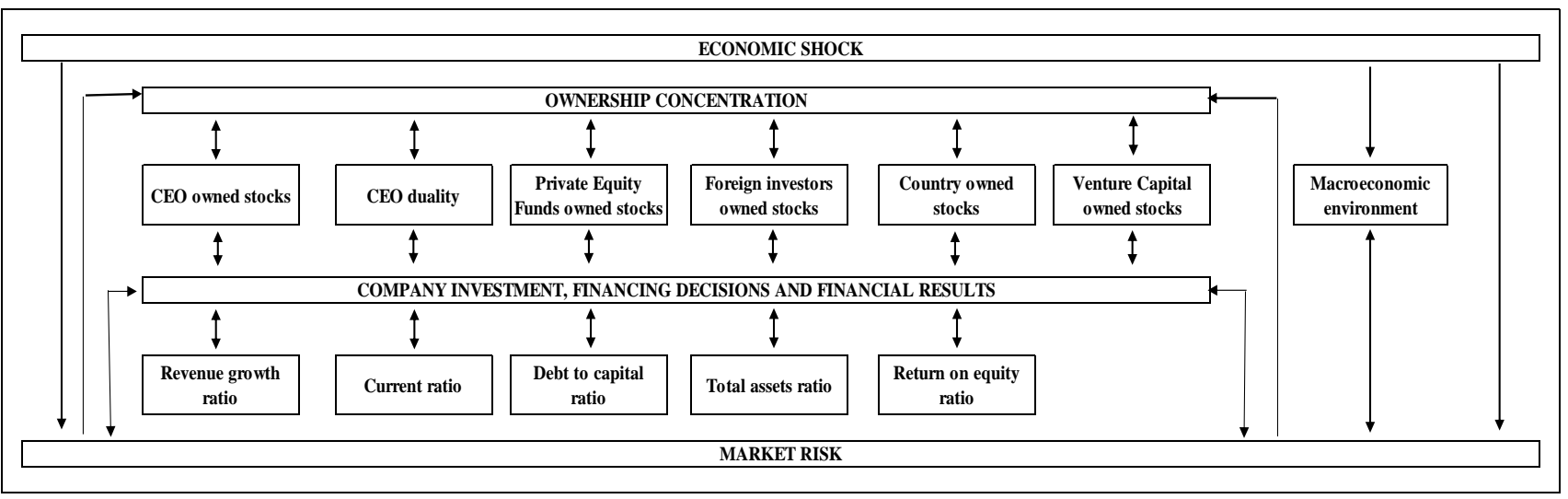

Figure. 1 The Conceptual Framework for the Analysis of the Interaction between Ownership Concentration and Market Risk Under the Conditions of an Economic Shock 
Figure 1 presents the conceptual point of view on the main sections of the ownership concentration analysis. An economic shock directly affects market risk, which, in its turn, interacts with ownership concentration. Ownership concentration has a bilateral effect on corporate investment and operational decisions, and vice versa. The meta-analysis of scientific literature allowed to identify 6 different ownership concentration ratios: CEO owned stocks, CEO duality, private equity fund owned stocks, foreign investor owned stocks, state owned stocks and venture capital owned stocks. Venture capital and private equity fund owned stocks are employed for assessment of the impact of ownership concentration on corporate financial ratios, stock price or investment decisions.

Ownership concentration indicators depicted in Figure 1 are recognised as having a significant impact on corporate operation, investment and funding decisions. CEO duality is recognised as a factor that has a positive impact on corporate efficiency (Leung et al., 2014; Cabrera-Suarez \& MartinSantana, 2014). Banks characterised by CEO duality usually face lower market risks (Dong, 2014), while CEO owned stocks tend to have a significant impact on corporate investment efficiency (Bao \& Lewellyn, 2017). An increase in private equity fund or business angels owned stocks lead to a decrease in corporate risks (Battaglia \& Gallo, 2017), while an increase in state owned stocks determines a reduction in corporate investment efficiency (Chen et al., 2017). Hence, the results of previous studies prove that ownership concentration indicators significantly affect corporate operation, funding and investment decisions as well as overall corporate performance, which substantiates that the topic of ownership concentration is extremely important and relevant in the context of the current economic shocks because these shocks have a significant impact on market risks, while the latter affect corporate decisions and performance. Considering the fact that investment and funding decisions as well as overall corporate performance are reflected in corporate market risks, it is expected that the results of this research will bring new methodological insights to both the discipline of economics and practical corporate decisions.

\section{Data and Research Methodology}

The interaction between ownership concentration and market risk is analysed by creating an ordinary least squares regression function (see Formula 1) based on the conceptual framework developed for ownership concentration analysis (see Figure 1). The regression function covers the following independent variables: return on equity, corporate debt ratio expressed as debt-to-equity ratio, current liquidity ratio, revenue growth rate and ownership concentration indicators represented by CEO duality, business angels owned stocks and private equity fund owned stocks. Beta risk indicator, which reflects corporate market risk, is included in the model as a dependent variable.

Because the area of the research is relatively new, the variables used for this research are based on previous scientific studies focused on the impact of ownership concentration on corporate operational, investment and funding decisions (Leung et al., 2014; Cabrera-Suarez \& Martin-Santana, 2014; Dong, 2014; Bao \& Lewellyn, 2017; Battaglia \& Gallo, 2017; Chen et al., 2017). CEO duality, business angels owned stocks and private equity fund owned stocks are selected to represent ownership concentration because the effects of these determinants on overall corporate performance and decisions is most significant.

The econometric model also incorporates Beta risk indicator (Battaglia \& Gallo, 2017) which reflects corporate market risk through the fluctuations in stock prices determined by the changes in the market.

Return on equity ratio, debt-to-equity ratio, revenue growth rate and corporate asset ratio are included in the econometric model based on Chen et al. (2017), Dong et al. (2014), and Cabrera-Suarez and Martin-Santana's (2014) studies because these studies identify the above-mentioned indicators as control indicators that raise the reliability of the econometric models developed for assessment of the impact of ownership concentration on corporate performance, decisions and risks.

$$
\begin{aligned}
& B E T A_{\text {risk }}=\beta 0+\beta 10 \text { wnership_PEF }+\beta 2 \text { CEO_Duality }+\beta 30 w n e r s h i p \_V e n \_C a p+\beta 4 \text { Rev_growth }+\beta 5 \text { Curr_Ratio }+ \\
& \beta 6 \text { Debt_Cap }+\beta \text { 7Tot_Assets }+\beta 8 \text { Return on equity }+u
\end{aligned}
$$

Table 1 presents the comprehensive list of the independent variables used for this research. The independent variables are selected based on scientific literature analysis and identification of the variables used in previous research (Leung et al., 2014; Cabrera-Suarez \& Martin-Santana, 2014; Dong, 2014; Bao \& Lewellyn, 2017; Battaglia \& Gallo, 2017; Chen et al., 2017).

The List of the Independent Variables used for the Research

Table 1

\begin{tabular}{|l|l|}
\hline \multicolumn{1}{|c|}{ Independent variable } & \multicolumn{1}{c}{ Description of the variable } \\
\hline$\beta 1$ Ownership_PEF & $\begin{array}{l}\text { The indicator included in the empirical formula reflects the share of private equity fund owned stocks. It is one of } \\
\text { ownership concentration indicators }\end{array}$ \\
\hline$\beta 2$ CEO_Duality & $\begin{array}{l}\text { The indicator reflects a CEO's position in a business company. It is an ownership concentration indicator that } \\
\text { shows whether a CEO at the same time holds the position of a chairman of the Board }\end{array}$ \\
\hline$\beta 3$ Ownership_Ven_Cap & $\begin{array}{l}\text { The variable represents the third ownership concentration indicator. It shows which share (percentage) of a } \\
\text { company is controlled by business angels }\end{array}$ \\
\hline$\beta 4$ Rev_growth & An independent variable which represents corporate revenue growth as a percentage \\
\hline$\beta 5$ Curr_Ratio & $\begin{array}{l}\text { This indicator reflects corporate current liquidity ratio. It shows a company's ability to meet current liquidity } \\
\text { needs for smooth business operation }\end{array}$ \\
\hline$\beta 6$ Debt_Cap & This indicator represents corporate debt-to-equity ratio \\
\hline$\beta 7$ Tot_Assets & This indicator represents total value of corporate assets in Euro \\
\hline$\beta 8$ Return on equity & This indicator represents corporate return on equity ratio \\
\hline
\end{tabular}


The unit of the research is listed companies from three different economic regions: Europe, America and China. The three different geographical regions are selected because of their highest concentration of business companies as well as the differences in socio-demographic and cultural characteristics, the level of economic development and investor protection. Due to the differences inherent to Europe, America and China, it is difficult for investors to equally treat the same type of information signals in the market, which means that the same type of market information may cause dissimilar investor reactions. It is important to note that business culture in the regions with different development levels is also dissimilar, which proposes that the relationship between corporate ownership concentration and corporate market risk can vary in its strength (Chen et al., 2017). It should be noted that the main risks faced by European, American and Chinese business companies are the same, but the level of risk impact may significantly vary. The companies that operate in developing economies are characterised by different business culture than the ones operating in developed economies, which makes it difficult to establish mutual trust based relationship because of a high risk of being deceived. In developed economies, implementation of a commodity or row material transaction is not difficult, while market competition is harsh. Thus, it is concluded that companies operating in different regions face the same market risk, the components of which, however, can have different effects. Therefore, the inclusion of markets with different characteristics raises reliability and versatility of the regression analysis.
Since US and China trade barriers wars and economic policy changes harms themselves, but gives indirect possibilities for other countries or unions like EU (Liu et al., 2020; Zhang et al., 2019) it is important to analyse if there exist differences of the ownership concentration impact for the companies market risk at the light of Brexit. In the researches authors compares the impact for China, US and EU as a huge and worldwide important countries or unions, thus, according to analysed publications, in this paper it is analysed the impact for EU America and China markets (Liu et al., 2020; Zhang et al., 2019).

The data for this research was extracted from Bloomberg database. The empirical research covers the year 2016 and the year 2018. The year 2016 was selected due to the fact that in 2016 the information on the UK leaving the EU was officially announced, while the year 2018 was included because in 2018 the exit process had already gained momentum, so corporate financial performance can be expected to reflect the impact of the UK's exit from the EU. Because the UK's exit from the EU has led to uncertainty about the future, especially for the UK business companies and the ones trading with the UK, BREXIT can be considered as a structural market shock. Due to market uncertainty in the future (i.e. due to what agreements will be signed concerning the movement of goods and the relationship between the $\mathrm{UK}$ and the EU), it is likely that all business companies operating within the UK or trading with this country are facing aberrant market risks.

Descriptive statistics of the panel data are presented in the Table 2 for 2016 year and Table 3 for the 2018 year.

The Descriptive Statistics of the Panel Data for Year 2016

\begin{tabular}{|c|c|c|c|c|c|c|c|c|c|}
\hline \multicolumn{5}{|c|}{ European companies. 2016.} & \multicolumn{5}{|c|}{ American companies. 2016.} \\
\hline Variable & Mean & S.D. & Min & Max & Variable & Mean & S.D. & Min & Max \\
\hline Beta_risk & 0,636 & 1,44 & $-65,8$ & 66,9 & Beta_risk & 0,829 & 6,44 & $-89,1$ & 93,7 \\
\hline Ownership_PEF & 0,495 & 5,12 & 0 & 100 & Ownership_PEF & 0,914 & 6,43 & 0 & 100 \\
\hline CEO_Duality & 0,116 & 0,321 & 0 & 1 & CEO_Duality & 0,344 & 0,475 & 0 & 1 \\
\hline Ownership_Ven_Cap & 0,371 & 3,99 & 0 & 100 & Ownership_Ven_Cap & 0,482 & 3,96 & 0 & 100 \\
\hline Rev_growth & 286 & $1,05 \mathrm{E}+04$ & $-1,94 \mathrm{E}+03$ & $8,13 \mathrm{E}+05$ & Rev_growth & 257 & $8,67 \mathrm{E}+03$ & -289 & $6,23 \mathrm{E}+05$ \\
\hline Curr_Ratio & 13 & 554 & $-11,1$ & $4,80 \mathrm{E}+04$ & Curr_Ratio & 4,97 & 36,2 & $-0,000468$ & 1400 \\
\hline Debt_Cap & 44,1 & 281 & 0 & $1,52 \mathrm{E}+04$ & Debt_Cap & 98,1 & 2180 & 0 & $1,67 \mathrm{E}+05$ \\
\hline Tot_Assets & $5,31 \mathrm{E}+09$ & $5,44 \mathrm{E}+10$ & 499 & $2,19 \mathrm{E}+12$ & Tot_Assets & $5,54 \mathrm{E}+09$ & $6,25 \mathrm{E}+10$ & -17 & $3,29 \mathrm{E}+12$ \\
\hline Return on equity & $-3,54$ & 94,1 & $-6,89 \mathrm{E}+03$ & $1,06 \mathrm{E}+03$ & Return on equity & $-23,2$ & 248 & -6980 & 15900 \\
\hline \multicolumn{5}{|c|}{ Chineese companies. 2016.} & \multicolumn{5}{|c|}{ UK companies. 2016.} \\
\hline Variable & Mean & S.D. & Min & Max & Variable & Mean & S.D. & Min & Max \\
\hline Beta_risk & 0,929 & 2,98 & $-76,7$ & 88,2 & Beta_risk & 0,655 & 0,884 & $-22,7$ & 10,1 \\
\hline Ownership_PEF & 0,569 & 4,08 & 0 & 97,2 & Ownership_PEF & 0,768 & 3,54 & 0 & 55,5 \\
\hline CEO_Duality & 0,227 & 0,419 & 0 & 1 & CEO_Duality & 0,037 & 0,189 & 0 & 1 \\
\hline Ownership_Ven_Cap & 0,6 & 4,71 & 0 & 100 & Ownership_Ven_Cap & 0,937 & 3,7 & 0 & 40,4 \\
\hline Rev_growth & 401 & $2,34 \mathrm{E}+04$ & -100 & $1,47 \mathrm{E}+06$ & Rev_growth & 36,9 & 374 & $-99,4$ & $1,01 \mathrm{E}+04$ \\
\hline Curr_Ratio & 2,58 & 3,6 & 0 & 75,2 & Curr_Ratio & 3,46 & 8,9 & 0 & 144 \\
\hline Debt_Cap & 28,9 & 57,6 & 0 & $3,24 \mathrm{E}+03$ & Debt_Cap & 40,9 & 474 & 0 & $1,47 \mathrm{E}+04$ \\
\hline Tot_Assets & $7,87 \mathrm{E}+09$ & $1,01 \mathrm{E}+11$ & 0 & $3,42 \mathrm{E}+12$ & Tot_Assets & $1,22 \mathrm{E}+10$ & $1,10 \mathrm{E}+11$ & 0 & $2,37 \mathrm{E}+12$ \\
\hline Return on equity & 6,19 & 23,9 & -521 & 176 & Return on equity & $-1,89$ & 79,2 & -540 & $1,76 \mathrm{E}+03$ \\
\hline
\end{tabular}


The Descriptive Statistics of the Panel Data for Year 2018

\begin{tabular}{|c|c|c|c|c|c|c|c|c|c|}
\hline \multicolumn{5}{|c|}{ European companies. 2018.} & \multicolumn{5}{|c|}{ American companies. 2018.} \\
\hline Variable & Mean & S.D. & Min & Max & Variable & Mean & S.D. & Min & Max \\
\hline Beta_risk & 0,639 & 1,25 & $-48,9$ & 62,5 & Beta_risk & 0,811 & 4,91 & $-66,3$ & 64,9 \\
\hline Ownership_PEF & 0,862 & 6,71 & 0 & 100 & Ownership_PEF & 1,57 & 8,33 & 0 & 100 \\
\hline CEO_Duality & 0,116 & 0,321 & 0 & 1 & CEO_Duality & 0,318 & 0,466 & 0 & 1 \\
\hline Ownership_Ven_Cap & 0,731 & 5,8 & 0 & 100 & Ownership_Ven_Cap & 0,705 & 4,79 & 0 & 88,1 \\
\hline Rev_growth & 255 & $1,22 \mathrm{E}+04$ & -292 & $9,29 \mathrm{E}+05$ & Rev_growth & 4020 & 254000 & -1630 & $2,05 \mathrm{E}+07$ \\
\hline Curr_Ratio & 6,56 & 134 & 0 & $9,77 \mathrm{E}+03$ & Curr_Ratio & 5,92 & 75,6 & 0 & 4960 \\
\hline Debt_Cap & 37,3 & 54,6 & 0 & $1,05 \mathrm{E}+03$ & Debt_Cap & 123 & 2940 & 0 & 167000 \\
\hline Tot_Assets & $6,99 \mathrm{E}+09$ & $6,08 \mathrm{E}+10$ & 0 & $2,04 \mathrm{E}+12$ & Tot_Assets & $6,29 \mathrm{E}+09$ & $6,33 \mathrm{E}+10$ & 0 & $2,98 \mathrm{E}+12$ \\
\hline Return on equity & $-2,65$ & 53,2 & $-1,46 \mathrm{E}+03$ & 353 & Return on equity & $-25,1$ & 205 & -6980 & 6180 \\
\hline \multicolumn{5}{|c|}{ Chine ese companies. 2018.} & \multicolumn{5}{|c|}{ UK companies. 2018.} \\
\hline Variable & Mean & S.D. & Min & Max & Variable & Mean & S.D. & Min & Max \\
\hline Beta_risk & 0,925 & 1,13 & -43 & 18,1 & Beta_risk & 0,7 & 0,536 & $-4,96$ & 13 \\
\hline Ownership_PEF & 0,621 & 4,59 & 0 & 94,1 & Ownership_PEF & 0,78 & 4,21 & 0 & 73,1 \\
\hline CEO_Duality & 0,232 & 0,422 & 0 & 1 & CEO_Duality & 0,0265 & 0,161 & 0 & 1 \\
\hline Ownership_Ven_Cap & 0,603 & 4,34 & 0 & 85,9 & Ownership_Ven_Cap & 0,893 & 3,68 & 0 & 48,6 \\
\hline Rev_growth & 20,9 & 164 & -105 & $6,77 \mathrm{E}+03$ & Rev_growth & 35,4 & 238 & -211 & $4,71 \mathrm{E}+03$ \\
\hline Curr_Ratio & 2,47 & 3,55 & 0 & 95,7 & Curr_Ratio & 3,78 & 11,2 & 0 & 212 \\
\hline Debt_Cap & 27,9 & 30,2 & 0 & 683 & Debt_Cap & 380 & $1,24 \mathrm{E}+04$ & 0 & $4,35 \mathrm{E}+05$ \\
\hline Tot_Assets & $7,78 \mathrm{E}+09$ & $9,76 \mathrm{E}+10$ & 0 & $3,52 \mathrm{E}+12$ & Tot_Assets & $8,95 \mathrm{E}+09$ & $8,64 \mathrm{E}+10$ & 0 & $2,23 \mathrm{E}+12$ \\
\hline Return on equity & 4,17 & 27,6 & -578 & 137 & Return on equity & $-6,06$ & 60,1 & -476 & $1,08 \mathrm{E}+03$ \\
\hline
\end{tabular}

The research sample for 2016 comprises 21453 business companies from the UK, Europe, America and China, while the research sample for 2018 comprises 22910 business companies from the same regions. The companies in the research represent various business sectors. Also, because BREXIT is an influential economic phenomenon associated with market risks, a separate group of business companies was formed to represent the UK. Formation of this separate group in the total sample of the research was based on the analysis of previous scientific studies that model the impact of BREXIT on FDI (Valverde \& Latorre, 2019), stock price fluctuations (Davies \& Studnicka, 2017), and the changes in import and export flows caused by possible restrictions (Lawless \& Morgenroth, 2019). Previous scientific studies propose that BREXIT is going to affect the whole economy of the UK as well as every business company operating in this country and the market risk it faces.

During the empirical research, three hypotheses $(\mathrm{H})$ were raised:

$\mathrm{H} 1$ - when a CEO at the same time acts as a chairman of the Board, a company bears a statistically significantly lower market risk.

$\mathrm{H} 2$ - when the values of ownership concentration indicators (private equity fund and business angels owned stocks) are rising, corporate market risk is decreasing due to a higher level of monitoring and possibilities to participate in corporate decision making.

H3 - the impact of ownership concentration on corporate market risk statistically significantly varies for the companies operating in different economic regions.

The stages of the empirical research are as follows: 1 . Overview of the macroeconomic situation in the regions under consideration. 2. Estimation of the indicators that reflect the impact of ownership concentration on corporate market risks in the UK, Europe, America and China; identification of statistically significant differences (if any) inherent to corporate market risks in particular economic regions. 3. Identification of the links (if any) between BREXIT and corporate market risks.

\section{Research Results}

Summary of macroeconomic indicators is presented in the Table 4. Results shows that the impact of Brexit caused lower amount of foreign direct investments received by United Kingdom. Moreover, it is shown that average beta risk level of United Kingdom companies increased comparing 2016 and $2018 \mathrm{y}$.

Summary of the Macroeconomic Indicators

\begin{tabular}{|c|c|c|c|c|}
\hline & Region / country & Year 2016 & Year 2018 & Change in percentage \\
\hline Real GDP growth (\%) & \multirow{5}{*}{ Europe } & 1.88 & 1.88 & $0.00 \%$ \\
\hline Unemployment rate & & 8.54 & 6.83 & $-1.71 \%$ \\
\hline FDI outflows & & 437.02 & 320.10 & $-26.75 \%$ \\
\hline FDI inflows & & 581.17 & 348.94 & $-39.96 \%$ \\
\hline Average Beta risk & & 0.64 & 0.64 & $0.00 \%$ \\
\hline Real GDP growth (\%) & \multirow{4}{*}{ United Kingdom } & 1.92 & 1.39 & $-27.60 \%$ \\
\hline Unemployment rate & & 4.81 & 4.00 & $-0.81 \%$ \\
\hline FDI outflows & & 37.59 & 41.42 & $10.19 \%$ \\
\hline FDI inflows & & 258.57 & 65.28 & $-74.75 \%$ \\
\hline
\end{tabular}


Inzinerine Ekonomika-Engineering Economics, 2020, 31(5), 502-512

\begin{tabular}{|c|c|c|c|c|}
\hline & Region / country & Year 2016 & Year 2018 & Change in percentage \\
\hline Average Beta risk & & 0.65 & 0.70 & $7.69 \%$ \\
\hline Real GDP growth (\%) & \multirow{5}{*}{ United States of America } & 1.64 & 2.93 & $78.66 \%$ \\
\hline Unemployment rate & & 4.87 & 3.90 & $-0.97 \%$ \\
\hline FDI outflows & & 309.90 & 68.41 & $-77.93 \%$ \\
\hline FDI inflows & & 486.02 & 268.44 & $-44.77 \%$ \\
\hline Average Beta risk & & 0.83 & 0.81 & $-2.41 \%$ \\
\hline Real GDP growth (\%) & \multirow{5}{*}{ China } & 6.70 & 6.60 & $-1.49 \%$ \\
\hline Unemployment rate & & 4.50 & 4.42 & $-0.08 \%$ \\
\hline FDI outflows & & 216.42 & 96.47 & $-55.42 \%$ \\
\hline FDI inflows & & 174.75 & 203.49 & $16.45 \%$ \\
\hline Average Beta risk & & 0.93 & 0.92 & $-1.08 \%$ \\
\hline
\end{tabular}

Macroeconomic results presented in the Table 4 shows that the biggest differences of macroeconomic indicators comparing 2016 and 2018 years data exists in the United Kingdom data. Since, other regions did not experienced as big differences as United Kingdom data, it is observed that the economic shock - Brexit might be one of the reasons that caused higher differences in the data of regions analysed.

Table 5

The Results of the Econometric Models Developed for Assessment of the Impact of Ownership Concentration on Corporate Market Risk in 2016

\begin{tabular}{|c|c|c|c|c|c|c|c|c|c|c|c|c|}
\hline & \multicolumn{3}{|c|}{ Europe } & \multicolumn{3}{|c|}{ United States of America } & \multicolumn{3}{|c|}{ China } & \multicolumn{3}{|c|}{ United Kingdom } \\
\hline & Coefficient & $\mathrm{p}$-value & & Coefficient & p-value & & Coefficient & $\mathrm{p}$-value & & Coefficient & $\mathrm{p}$-value & \\
\hline const & 0,830 & $<0,0001$ & $* * *$ & 1,141 & $<0,0001$ & $* * * *$ & 1,050 & $<0,0001$ & $* * *$ & 1,096 & $<0,0001$ & $* * *$ \\
\hline Ownership_PEF & $-0,00162541$ & 0,247 & & 0,003 & 0,018 & $* *$ & 0,002 & 0,253 & & $-0,00322956$ & 0,884 & \\
\hline CEO_Duality & 0,017 & 0,477 & & $-0,0408605$ & 0,242 & & $-0,0985678$ & $<0,0001$ & $* * * *$ & 0,143 & 0,096 & $*$ \\
\hline Ownership_Ven_Cap & 0,000 & 0,860 & & 0,004 & 0,209 & & $-0,00673067$ & $<0,0001$ & $* * *$ & $-0,0114824$ & 0,198 & \\
\hline Rev_growth & $-6,02628 \mathrm{e}-07$ & 0,061 & $*$ & 0,000 & 0,906 & & $-0,000123197$ & 0,445 & & $-0,000895250$ & 0,064 & $*$ \\
\hline Curr_Ratio & 0,005 & 0,029 & $* *$ & 0,000 & 0,094 & $*$ & $-0,00502962$ & 0,134 & & 0,004 & 0,450 & \\
\hline Debt_Cap & 0,001 & 0,002 & $* * *$ & 0,000 & 0,492 & & 0,000 & 0,611 & & $-0,000192873$ & 0,775 & \\
\hline Tot_Assets & 0,000 & 0,002 & $* * *$ & $-8,95318 \mathrm{e}-013$ & 0,000 & $* * *$ & $-4,53464 \mathrm{e}-013$ & 0,284 & & 0,000 & 0,623 & \\
\hline Return on equity & $-0,000385131$ & 0,040 & $* *$ & $-0,000396296$ & 0,298 & & 0,001 & 0,019 & $* *$ & 0,000 & 0,517 & \\
\hline
\end{tabular}

* significant at $90 \%$; ** significant at $95 \%$; ** significant at $99 \%$ level.

Table 6

The Results of the Econometric Models Developed to Assess the Impact of Ownership Concentration on Corporate Market risk in 2018

\begin{tabular}{|c|c|c|c|c|c|c|c|c|c|c|c|c|}
\hline & \multicolumn{3}{|c|}{ Europe } & \multicolumn{3}{|c|}{ United States of America } & \multicolumn{3}{|c|}{ China } & \multicolumn{3}{|c|}{ United Kingdom } \\
\hline & Coefficient & $\mathrm{p}$-value & & Coefficient & $\mathrm{p}$-value & & Coefficient & $\mathrm{p}$-value & & Coefficient & $\mathrm{p}$-value & \\
\hline const & 0,922 & $<0,0001$ & $* * *$ & 1,066 & $<0,0001$ & $* * *$ & 0,992 & $<0,0001$ & $* * *$ & 0,871 & $<0,0001$ & $* * *$ \\
\hline Ownership_PEF & $-0,00327530$ & $\mathbf{0 , 0 1 4}$ & $* *$ & 0,002 & 0,211 & & 0,001 & 0,456 & & $-0,00632858$ & 0,711 & \\
\hline CEO_Duality & 0,011 & 0,730 & & $-0,0516148$ & 0,127 & & $-0,0371945$ & 0,096 & $*$ & 0,191 & $\mathbf{0 , 0 7 7}$ & $*$ \\
\hline Ownership_Ven_Cap & $-0,00227730$ & $\mathbf{0 , 0 8 5}$ & $*$ & 0,002 & 0,333 & & $-0,002$ & $\mathbf{0 , 0 8 5}$ & $*$ & $-0,0272193$ & $\mathbf{0 , 0 7 8}$ & $*$ \\
\hline Rev_growth & 0,001 & 0,248 & & 0,000 & 0,016 & $* *$ & 0,000 & 0,210 & & 0,001 & 0,016 & $* *$ \\
\hline Curr_Ratio & 0,014 & $\mathbf{0 , 0 3 0}$ & $* *$ & $-0,00580848$ & 0,120 & & 0,001 & 0,899 & & 0,008 & 0,416 & \\
\hline Debt_Cap & $-0,00119060$ & $\mathbf{0 , 0 3 5}$ & $* *$ & 0,001 & 0,594 & & 0,001 & 0,276 & & 0,001 & $\mathbf{0 , 0 8 7}$ & $*$ \\
\hline Tot_Assets & 0,000 & $<0,0001$ & $* * *$ & $-7,99583 \mathrm{e}-013$ & 0,010 & $* * *$ & $-2,65013 \mathrm{e}-013$ & 0,395 & & 0,000 & 0,233 & \\
\hline Return on equity & 0,001 & 0,094 & $*$ & $-0,000120095$ & 0,655 & & 0,001 & 0,275 & & $-9,46123 \mathrm{e}-05$ & 0,712 & \\
\hline
\end{tabular}

* significant at $90 \%$; * significant at $95 \%$;** significant at $99 \%$ level.

In the Table 5 and Table 6 the main results of created econometric models are presented for year 2016 and year 2018. It can be observed, that the results differs in the different regions and 2016 compared to 2018 years. Results shows, that the impact of ownership concentration can have both, negative and positive impact on the corporate market risk and can differ among the different markets.

\section{Discussion}

With reference to the data for 2016 (see Table 5), ownership concentration indicators do not have any statistically significant impact on corporate market risk faced by European business companies. The results of the models developed for America and the UK indicate that corporate market risk is statistically significantly affected by a single ownership concentration indicator, private equity fund owned stocks in America and CEO duality in the UK, respectively. It should be noted that the results obtained from Chinese research sample are slightly different: in 
Chinese sample, ownership concentration indicators statistically significantly affect corporate market risk under CEO duality and with business angels owned stocks. Summarising the results for 2016, it should be noted that economically developed countries or regions (in this research represented by Europe, America and the UK) do not record any statistically significant relationship between ownership concentration and corporate market risk or such relationship is inherent only to 1 out of 3 ownership concentration variables included in the empirical model. Meanwhile, in the model developed for China that represents a developing economy, a strong relationship (99\% of significance) between ownership concentration indicators - CEO duality and business angels owned stocks - and corporate market risk is observed. Also, when assessing the results of the research sample models developed for 2016, hypothesis $\mathrm{H} 1$ proposing that corporate market risk is statistically significantly lower under CEO duality cannot be confirmed; hypothesis $\mathrm{H} 2$ cannot be confirmed either because although a statistically significant impact of private equity fund owned stocks or business angels owned stocks on corporate market risk was identified, the direction of this impact varied for different regions (in the American sample, the variables tended to raise corporate market risk, while in the Chinese sample the variables tended to significantly reduce corporate market risk). It should be noted that the results obtained from the models confirm hypothesis H3. The impact of ownership concentration indicators on corporate market risk in American, UK, European and Chinese regions tends to vary.

Based on the research results for 2018 (see Table 6), it can be stated that in the European sample, a statistically significant relationship exists between 2 out of 3 ownership concentration indicators and corporate market risk. It can also be seen that when the share of private equity fund and business angels owned stocks is rising, corporate market risk is decreasing. In the American sample for 2018, no statistically significant relationship between ownership concentration indicators and corporate market risk can be observed. In the UK sample for 2018, 2 out of 3 ownership concentration indicators (significant at $90 \%$ ) have a statistically significant impact on corporate market risk. Thus, under CEO duality, the UK's business companies are exposed to statistically significantly higher market risk, while a rising share of business angels owned stocks leads to statistically significantly lower market risk. The results obtained from the Chinese sample for 2018 indicate that CEO duality and business angels owned stocks are statistically significant ownership concentration indicators that affect market risk.

Comparing the results of the 2016 sample and the 2018 sample, it can be seen that the directions of the impact of ownership concentration indicators on corporate market risk remain the same. The key point worth mentioning is that the impact of ownership concentration indicators on corporate market risk in economically highly developed countries or regions, represented by the UK, the USA and Europe, was either statistically insignificant or relatively little significant (significant at $95 \%$ ), which proposes that due to a high level of investor protection and transparency, neither the changes in ownership concentration (i.e. growth or decline in the share of private equity fund or business angels owned stocks), nor CEO duality in business companies that operate in economically highly developed regions have any significant impact on corporate market risk. The results obtained from the Chinese sample, in particular for 2016, indicate that there exists a strong and statistically significant relationship between ownership concentration (CEO duality and business angels owned stocks) and corporate market risk in China.

Based on the research results, hypothesis $\mathrm{H} 3$, proposing that the impact of ownership concentration on corporate market risk statistically significantly varies for the companies operating in different economic regions, is accepted. The results also indicate that although the impact of the variables in the empirical models manifests in the same directions comparing 2016 and 2018, the significance of the variables greatly varies. In addition, it can be considered that solely normal economic development in the UK would not have led to such significant differences in the results of the models developed for 2016 and 2018, which proposes that there exists a relationship between BREXIT and decreased FDI as well as BREXIT and increased corporate market risk. Hypotheses $\mathrm{H} 1$ and $\mathrm{H} 2$ cannot be accepted because the results of the empirical models indicate that the changes in CEO duality and private equity fund owned stocks can have a statistically significant bidirectional impact on corporate market risk in different regions.

Comparing the findings of this study with the findings of previous studies, it can be seen that the result of testing hypothesis H1 is not in line with Cabrera-Suarez and Martin-Santana's (2014) or Vintila and Gherghina's (2014) results because this study has revealed a statistically significant bidirectional impact of ownership concentration on corporate market risk in different regions with CEO duality having a negative impact on corporate market risk. Because this study addresses regions or countries with different levels of economic development, investor protection and transparency, it can be considered that discrepancies with the results of previous studies are plausible since the sample of this research is expanded. The findings of this study in relation to hypothesis $\mathrm{H} 2$, proposing that when the values of ownership concentration indicators are rising, corporate market risk is decreasing, are not in line with the findings of some previous studies. For instance, Cabrera-Suarez and Martin-Santana (2014) as well as Vintila and Gherghina (2014) accept hypothesis H2 due to the possibilities of a higher level of corporate monitoring. A part of the models developed in this study, however, indicate that when the share of business angels or private equity fund owned stocks is increasing, no statistically significant changes in corporate market risk are observed or the changes occur in the opposite direction. This result can be determined by the fact that companies in the research samples were not divided by sectors because business companies operating in different industrial sectors may respond differently to the changes in ownership concentration. In addition, since the samples in the comparative research were smaller and covered one country, it can be presumed that the results may show different interdependencies when analysing a larger array of data. Because the sample was expanded (by including 
particular regions and assessing the impact of BREXIT) to ensure the novelty of the research, the results of testing hypothesis H3 cannot be compared with the results of previous studies. Moreover, when talking about the impact of Brexit, results of the research shows that FDI of the UK decreased and the corporate risk of the UK companies increased, like it was presented in the researches of Batsaikhan et al. (2017) and Bailey et al. (2018). Thus, the idea that uncertainty of the future of the UK (monetary policy, trade barriers, etc.) might cause even bigger losses for the UK at the leaving moment because it already has affected the FDI and market risk of the UK companies.

\section{Conclusion, Limitations and Further Research}

The results of this research allow to accept hypothesis $\mathrm{H} 3$ proposing that the impact of ownership concentration on corporate market risk statistically significantly varies for the companies operating in different economic regions. The results also indicate that although the impact of the variables in the empirical models manifests in the same directions comparing 2016 and 2018, the significance of the variables greatly varies. It can be considered that solely normal economic development in the UK would not have led to such significant differences in the results of the models developed for 2016 and 2018, which proposes that there exists a relationship between BREXIT and decreased FDI as well as BREXIT and increased corporate market risk. Hypotheses $\mathrm{H} 1$ and $\mathrm{H} 2$ cannot be accepted because the results of the empirical models indicate that the changes in CEO duality and private equity fund owned stocks can have a statistically significant bidirectional impact on corporate market risk in different regions.

We also concede that our research was hampered by the inherent limitations:

- the period considered in this research covers the year 2016 and the year 2018 because the data of these years reflect the beginning and the advanced stage of the BREXIT process, respectively. In further research, the period under consideration could be supplemented with the actual term of BREXIT and the later term that would reflect the effects of BREXIT following its the entry into force as of a structural change.

- the limitation of the research method lies in application of the ordinary least squares regression model. For expanding or developing the research, other variables and other methods of constructing an econometric model can be employed.

There is a number of future research opportunities since this investigation area is still novel.

First of all, we propose to assess the impact of ownership concentration on corporate market risk over a longer period.

Secondly, the assessment of BREXIT's impact on corporate market risk could be complemented with the data covering the period from BREXIT announcement to its actual date.

Thirdly, further assessment of the impact of ownership concentration on corporate market risk could be complemented with consideration of how the changes in ownership concentration affect corporate market risk when business companies are grouped by sector because there is a reason to presume that ownership concentration indicators can have different effects on business companies operating in different sectors.

Also, further research could employ a larger number of ownership concentration indicators, thus refining the essential ones that have the most significant impact on corporate market risk.

By expanding the area under consideration, further research could assess to which extent ownership concentration, representing one of the areas of corporate business management, affects corporate market risk in comparison to the effects made by other areas of corporate business management.

\section{Reference}

Arosa, B. (2010). Outsiders on the board of directors and firm performance: Evidence from Spanish non-listed family firms. Journal of Family Business Strategy, 1 (4), 236-245. https://ideas.repec.org/a/eee/fambus/v1y2010i4p236-245.html. https://doi.org/10.1016/j.jfbs.2010.10.004

Bailey, D., Driffield, N., \& Kispeter, E. (2019). Brexit, foreign investment and employment: some implications for industrial policy?, Contemporary Social Science, 14(2), 174-188. https://doi.org/10.1080/21582041.2019.1566563.

Bao, S., \& Lewelyn, K. (2017). Ownership structure and earnings management in emerging markets-An institutionalized agency perspective. International Business Review, 26(5), 828-838. https://ideas.repec.org/a/eee/iburev/v26y2017i5

p828-838.html. https://doi.org/10.1016/j.ibusrev.2017.02.002

Barinov, A. (2017). Institutional ownership and aggregate volatility risk. Journal of Empirical Finance, 40, $20-38$. https://ideas.repec.org/a/eee/empfin/v40y2017icp20-38.html. https://doi.org/10.1016/j.jempfin.2016.11.003

Barunik, J., \& Krehlik, T. (2018). Measuring the Frequency Dynamics of Financial Connectedness and Systemic Risk. Journal of Financial Econometrics, 16, 271-296. https://ideas.repec.org/a/oup/jfinec/v16y2018i2p271-296..html. https://doi.org/10.1093/jjfinec/nby001

Batsaikhan, U., Kalcik, R., \& Schoenmaker, D. (2017). Brexit and the European financial system: mapping markets, players and jobs, Bruegel Policy Contribution, No. 2017/4, Bruegel, Brussels. This Version is available at: http://hdl.handle.net/10419/173100

Battaglia, F., \& Gallo, A. (2017). Strong boards, ownership concentration and EU banks' systemic risk-taking: Evidence from the financial crisis. Journal of International Financial Markets, Institutions and Money, 46, $128-146$. https://ideas.repec.org/a/eee/intfin/v46y2017icp128-146.html. https://doi.org/10.1016/j.intfin.2016.08.002 
Jurgita Bruneckiene, Sarunas Mikalonis, Jonas Rapsikevicius. The Interaction between Ownership Concentration and ...

Ben-Nasi, H., \& Cosset, J. (2014). State Ownership, Political Institutions, and Stock Price Informativeness: Evidence from Privatization. Journal of Corporate Finance, 29, 179-199. https://ideas.repec.org/a/eee/corfin/v29y2014icp179199.html. https://doi.org/10.1016/j.jcorpfin.2014.10.004

Cabrera-Suarez, K., \& Martin-Santana, J. (2014). Board composition and performance in Spanish non-listed family firms: The influence of type of directors and CEO duality. BRQ Business Research Quarterly, 18, $213-229$. https://www.sciencedirect.com/science/article/pii/S2340943614000632. https://doi.org/10.1016/j.brq.2014.08.001

Campbell, J. (2015). Ownership and pricing of information: A model and application to open access. Information Economics and Policy, 33, 29-42. https://ideas.repec.org/a/eee/iepoli/v33y2015icp29-42.html. https://doi.org/10.1016/ j.infoecopol.2015.10.001

Chen, R. (2017). Do state and foreign ownership affect investment efficiency? Evidence from privatizations. Journal of Corporate Finance, 42, 408-421. https://ideas.repec.org/a/eee/corfin/v42y2017icp408-421.html. https://doi.org/10.10 16/j.jcorpfin.2014.09.001

Danielsson, J., Macrae, R., Micheler, E. (2017). Brexit and the implications for financial services, SUERF Conference Proceedings, No. 2017/1, ISBN 978-3-902109-84-2, SUERF - The European Money and Finance Forum, Vienna

Davies, B., \& Studnicka, Z. (2017). The heterogeneous impact of Brexit: Earlyindications from the FTSE. Available from internet: https://papers.ssrn.com/sol3/papers.cfm?abstract_id=2985332.

Ding, R. (2013). Fund ownership and stock price informativeness of Chinese listed firms. Journal of Multinational Financial Management, 23, 166-185. https://doi.org/10.1016/j.mulfin.2013.03.003.

Dong, Y., \& others (2014). Ownership structure and risk-taking: Comparative evidence from private and state-controlled banks in China. International Review of Financial Analysis, 36, 120-130. https://ideas.repec.org/a/eee/finana/ v36y2014icp 120-130.html. https://doi.org/10.1016/j.irfa.2014.03.009

Drobetz, W., Janzen, M., \& Requejo, I. (2019). Capital allocation and ownership concentration in the shipping industry. Transportation Research Part E: Logistics and Transportation Review, 122, 78-99. https://ideas.repec.org/a/eee/transe/v122y2019icp78-99.html. https://doi.org/10.1016/j.tre.2018.09.010

Eugster, N., \& Isakov, D. (2019). Founding family ownership, stock market returns, and agency problems. Journal of Banking \& Finance, 107, 1-11. https://ideas.repec.org/a/eee/jbfina/v107y2019ic7.html. https://doi.org/10.1016 /j.jbankfin.2019.07.020

Farrer, J., \& Ramsay, I. (1998). Director Share Ownership and Corporate Performance - Evidence from Australia. Corporate governance: An International Review, 6, 233-248. https://doi.org/10.1111/1467-8683.00112.

Feng, X., Hu, N., \& Johansson, A. (2016). Ownership, analyst coverage, and stock synchronicity in China. International Review of Financial Analysis, 45, 79-96. http://www.sciencedirect.com/science/article/pii/S1057521916300102. https://doi.org/10.1016/j.irfa.2016.02.002

Gonzalez, M., \& others (2016). The effect of ownership concentration and composition on dividends: Evidence from Latin America. Emerging Markets Review, 30, 1-18. https://ideas.repec.org/a/eee/ememar/v30y2017icp1-18.html. https://doi.org/10.1016/j.ememar.2016.08.018

Grossule, E. (2019). Risks and Benefts of the Increasing Role of ESMA: A Perspective from the OTC Derivatives Regulation in the Brexit Period. European Business Organization Law Review, 21, 393-414. https://doi.org/10. 1007/s40804-019-00147-x.

Haw, I., \& others (2013). Legal Institutions, Ownership Concentration, and Stock Repurchases Around the World: Signal Mimicking? The International Journal of Accounting, 48, 427-458. https://ideas.repec.org/a/eee/ accoun/v48y2013i4p427-458.html. https://doi.org/10.1016/j.intacc.2013.10.004

Hou, W., Kuo, J., \& Lee, E. (2012). The impact of state ownership on share price informativeness: The case of the Split Share Structure Reform in China. The British Accounting Review, 44, 248-261. https://doi.org/10.1016/j.bar. 2012.09.003.

Lawless, M., \& Morgenroth, E. (2019). The product and sector level impact of a hard Brexit across the EU. Contemporary Social Science, 14, 189-207. https://econpapers.repec.org/article/tafrsocxx/v_3a14_3ay_3a2019_3ai_3a2_3ap _3a189-207.htm. https://doi.org/10.1080/21582041.2018.1558276

Leung, S., \& others (2014). Corporate board and board committee independence, firm performance, and family ownership concentration: An analysis based on Hong Kong firms. Journal of Contemporary Accounting \& Economics, 10 (1), 16-31. https://ideas.repec.org/a/eee/jocaae/v10y2014i1p16-31.html. https://doi.org/10.1016/j.jcae.2013.11.002

Li, H. (2020). Volatility spillovers across European stock markets under the uncertainty of Brexit. Economic Modelling, 84, 1-12. https://doi.org/10.1016/j.econmod.2019.03.001.

Liu, L., \& others (2020). Environmental and economic impacts of trade barriers: The example of China-US trade friction. Resource and Energy Economics, 59. https://doi.org/10.1016/j.reseneeco.2019.101144. 
Manzaneque, M., Merino, E., Priego, A. (2016). The role of institutional shareholders as owners and directors and the financial distress likelihood. Evidence from a concentrated ownership context. European management journal, 34, 439-451. https://doi.org/10.1016/j.emj.2016.01.007.

Neveu, A. R. (2018). A survey of network-based analysis and systemic risk measurement. Journal of Economic Interaction and Coordination, 13, 241-281. https://ideas.repec.org/a/spr/jeicoo/v13y2018i2d10.1007_s11403-016-0182-z.html. https://doi.org/10.1007/s11403-016-0182-z

Prommin, P., \& others (2016). Liquidity, ownership concentration, corporate governance, and firm value: Evidence from Thailand. Global Finance Journal, 31, 73-87. https://ideas.repec.org/a/eee/glofin/v31y2016icp73-87.html. https://doi.org/10.1016/j.gfj.2016.06.006

Silva, T. C., Silva, M. A., Tabak, B. M. (2017). Systemic risk in financial systems: A feedback approach. Journal of Economic Behavior \& Organization, 144, 97-120. https://ideas.repec.org/a/eee/jeborg/v144y2017icp97-120.html. https://doi.org/10.1016/j.jebo.2017.09.013

Steinberg, J. (2019). Brexit and the macroeconomic impact of trade policy uncertainty. Journal of International Economics, 117, 175-195. https://doi.org/10.1016/j.jinteco.2019.01.009.

Stepanov, S., \& Suvorov, A. (2017). Agency problem and ownership structure: Outside blockholder as a signal. Journal of Economic Behavior \& Organization, 133, 87-107. https://ideas.repec.org/a/eee/jeborg/v133y2017icp87-107.html. https://doi.org/10.1016/j.jebo.2016.10.024

Sun, J., \& others (2016). Ownership, capital structure and financing decision: Evidence from the UK. The British Accounting Review, 48, 448-463. https://doi.org/10.1016/j.bar.2015.04.001.

Valverde, G., \& Latorre, M. (2019). Economic Analysis of Multinationals Firms in the UK after Brexit. Available from internet: https://www.gtap.agecon.purdue.edu/resources/res_display.asp?RecordID=5849.

Vintila, G., \& Gherghina, S. (2014). The impact of ownership concentration on firm value. Empirical study of the Bucharest Stock Exchange listed companies. Procedia Economics and Finance, 15, 271-279. https://doi.org/10.1016/S22125671(14)00500-0.

Welfens, P. J. J. (2019). Lack of international risk management in BREXIT? International Economics and Economic, 16, 103-160. https://doi.org/10.1007/s10368-019-00433-6.

Wen, H., \& Xia, K. (2016). Venture Capital, Ownership Concentration and Enterprise R\&D Investment. Procedia Computer Science, 91, 519-525. https://doi.org/10.1016/j.procs.2016.07.133.

Zhai, P., \& Ma, R. (2017). Does ownership structure affect trade credit policy in small- and medium-sized firms? Evidence from China. Ensayos sobre Politica Economica, 35, 130-138. https://doi.org/10.1016/j.espe.2017.01.001.

Zhang, D., \& others (2019). Economic policy uncertainty in the US and China and their impact on the global markets. Economic modelling, 79, 47-56. https://doi.org/10.1016/j.econmod.2018.09.028.

The article has been reviewed.

Received in May 2020; accepted in December 2020.

This article is an Open Access article distributed under the terms and conditions of the Creative Commons Attribution 4.0 (CC BY 4.0) License (http://creativecommons.org/licenses/by/4.0/). 